\title{
PENGARUH PRAKTIKUM VIRTUAL TERHADAP SIKAP ILMIAH SISWA SMA
}

\author{
Supriyadi \\ Program Studi Pendidikan Biologi Fakultas Tarbiyah dan Keguruan UIN Raden \\ Intan Lampung (Telp: 081367302075/surel: supriadi@ radenintan.ac.id)
}

Diterima : 10 Agustus 2017. Disetujui: 10 Desember 2017. Dipublikasikan: 29 Desember 2017

\begin{abstract}
Abstrak
Keberadaan laboratorium dalam pembelajaran biologi sangat penting, tetapi jarang digunakan karena keterbatasan waktu, alat dan bahan serta faktor resiko kecelakaan. Selain itu, sikap ilmiah siswa ssering luput dari perhatian guru. Salah satu upaya yang dapat dilakukan untuk mengatasi masalah tersebut adalah dengan menggunakan praktikum virtual.

Penelitian ini bertujuan untuk meningkatkan sikap ilmiah siswa pada konsep daur biogeokimia menggunakan praktikum virtual. Metode weak experiment dan desain the one-group pretest-posttest design digunakan dalam penelitian ini. Praktikum virtual diterapkan pada siswa kelas X SMA Negeri 1 Bandar Sribhawono Lampung Timur sebanyak dua kelas. Kelas X1 sebagai kelas eksperimen dan X2 sebagai kelas replikasi untuk memperkuat hasil penelitian.

Temuan penelitian menunjukkan bahwa praktikum virtual secara signifikan meningkatkan sikap ilmiah siswa kelas X pada konsep daur biogeokimia (Kelas X1 Ngain $=0,21 ; \mathrm{X} 2, N$-gain $=0,12$ ). Praktikum virtual pada konsep daur biogeokimia dapat digunakan oleh guru di sekolah sebagai alternatif pembelajaran untuk mengembangkan sikap ilmiah siswa.
\end{abstract}

Kata Kunci: sikap ilmiah; konsep daur biogeokimia; praktikum virtual

\section{PENDAHULUAN}

Pendidikan merupakan wilayah strategis dalam upaya mempersiapkan sumber daya manusia Indonesia berkualitas yang mampu bersaing di era globabilasasi. Berkenaan dengan hal tersebut pemerintah berkomitmen melalui Undang-undang Nomor 20 Tahun 2003 tentang Sistem Pendidikan Nasional (Sisdiknas) bahwa tujuan pendidikan di Indonesia antara lain untuk mengembangkan potensi siswa agar menjadi manusia yang bertaqwa kepada Tuhan Yang Maha Esa, berakhlak mulia, sehat, berilmu, 
cakap, kreatif, mandiri, dan menjadi warga negara yang demokratis serta bertanggung jawab.

Salah satu cara mencapai tujuan pendidikan tersebut adalah dengan menciptakan pembelajaran yang berkualitas. Pembelajaran berkualitas yang dimaksud yakni pembelajaran yang dapat memfasilitasi siswa mengaplikasikan pengetahuan dan keterampilan berpikir terbaiknya, mempunyai sikap disiplin, jujur, dan bertanggung jawab yang merupakan perwujudan karakter bangsa.

Hakikat mata pelajaran IPA, termasuk biologi meliputi produk, proses, dan sikap. IPA sebagai produk antara lain ditemukan fakta, konsep, prinsip, dan teori melalui proses berpikir. IPA sebagai proses berarti dalam proses pembelajaran siswa dilatih mengembangkan pengetahuan melalui keterampilan proses. Sedangkan IPA sebagai sikap maknanya bahwa dalam proses belajar menemukan produk IPA, siswa harus dibekali karakter terpuji yaitu sikap ilmiah (Rustaman et al., 2003). Senada dengan pernyataan tersebut, Carin (1997) menjelaskan bahwa sebagai suatu bangun ilmu, IPA terbentuk dari interrelasi antara sikap dan proses sains, penyelidikan fenomena alam, dan produk keilmuan. Dengan demikian, pembelajaran biologi hendaknya membelajarkan siswa untuk mengasah keterampilan berpikir, keterampilan proses yang diiringi dengan sikap ilmiah yang baik sebagai upaya mengembangkan karakter bangsa.

Kegiatan praktikum merupakan salah satu metode pembelajaran yang dapat digunakan agar proses pembelajaran IPA menjadi berkualitas bagi siswa. Berbagai penelitian terbaru menunjukkan bahwa siswa lebih terlibat dalam pembelajaran ketika materi disajikan dengan strategi pembelajaran aktif. Sejalan dengan hal tersebut, Woolnough dan Allsop (dalam Rustaman et al.,2003) mengemukakan empat alasan 
pentingnya kegiatan praktikum IPA, khususnya biologi yaitu: (1) praktikum dapat membangkitkan motivasi belajar IPA bagi siswa, karena siswa diberi kesempatan untuk memenuhi dorongan rasa ingin tahu dan ingin bisa; (2) praktikum dapat mengembangkan keterampilan dasar melakukan eksperimen; (3) praktikum dapat menjadi wahana belajar pendekatan ilmiah; (4) praktikum dapat menunjang materi pelajaran. Sesuai uraian tersebut dapat disimpulkan bahwa kegiatan praktikum memberikan kesempatan kepada siswa untuk membuktikan teori bahkan menemukan teori. Selain itu, praktikum dalam pelajaran biologi dapat membentuk ilustrasi bagi konsep dan prinsip biologi.

Saat ini, pembelajaran biologi yang dapat meningkatkan sikap ilmiah siswa perlu dikembangkan agar siswa memiliki jiwa seorang saintis dan terbentuk generasi berkarakter. Upaya menciptakan pembelajaran yang bernuansa pengembangan sikap ilmiah juga diharapkan dapat memperbaiki mutu proses pembelajaran biologi di sekolah. Hal ini perlu mendapat perhatian karena Bassham et al. (2007) menyatakan bahwa kebanyakan sekolah cenderung menekankan keterampilan berpikir tingkat rendah dalam pembelajarannya serta jarang memperhatikan aspek sikap ilmiah. Siswa hanya menyerap informasi secara pasif dan kemudian mengulanginya atau mengingatnya pada saat mengikuti tes. Hal ini sesuai dengan temuan studi pendahuluan bahwa guru biologi di SMAN 1 Bandar Sribhawono belum mengembangkan sikap ilmiah siswa secara optimal.

Seiring dengan kemajuan teknologi dan informasi, kegiatan praktikum yang biasanya diajarkan di laboratorium sekolah dapat diajarkan secara virtual (Maldarelli et al., 2009). Praktikum virtual sebagai produk dari kemajuan teknologi diharapkan dapat menjadi solusi untuk mengatasi hambatan-hambatan dalam melaksanakan praktikum 
biologi. Permasalahan yang berkaitan dengan waktu dalam melakukan kegiatan praktikum di laboratorium, dapat diatasi dengan adanya praktikum virtual.

Praktikum virtual merupakan sebuah simulasi komputer yang memungkinkan fungsi-fungsi penting dari laboratorium riil dilaksanakan pada komputer. Praktikum virtual dikembangkan dengan memperhatikan dua konsep utama yaitu (1) praktikum riil digantikan oleh komputer dalam bentuk simulasi. (2) praktikum riil digambarkan secara virtual di mana kegiatan praktikum dimanipulasi dengan alat komputer. Praktikum virtual dikembangkan dengan menggabungkan teknologi, software yang dapat digunakan kembali dan bersifat otomatis (Greenberg dan Research (dalam Babateen, 2011). Menurut Roberts (dalam Babateen, 2011) menggunakan praktikum virtual memiliki kelebihan-kelebihan antara lain: (1) menghasilkan kinerja siswa yang setara dengan atau lebih baik dibandingkan praktikum riil; (2) mengurangi kebutuhan peralatan dan ruang laboratorium, sehingga menghemat biaya; (3) menghemat waktu praktikum; (4) lebih fleksibel karena siswa dapat bereksperimen di luar sekolah pada setiap saat; (5) keselamatan kerja menggunakan praktikum virtual lebih aman.

Praktikum virtual menurut Carnevale (2003) dapat memberikan keleluasaan (flexibility) terhadap waktu dan tempat dalam melakukannya. Hambatan lain seperti kesulitan mendapatkan bahan praktikum atau beresiko karena bahan tersebut berada di lingkungan yang berbahaya dapat diatasi dengan kegiatan praktikum virtual. Lebih lanjut Hill dan Nelson (2011) menjelaskan bahwa praktikum virtual memberikan pengalaman bereksperimen yang aman dan menyenangkan bagi siswa. Pemanfaatan teknologi virtual dapat membawa berbagai jenis lingkungan atau ekosistem alami yang eksotis dengan komponen-komponennya ke dalam kelas, sehingga diharapkan dapat membantu mengatasi keterbatasan alat dan bahan dalam melakukan kegiatan praktikum 
Konsep daur biogeokimia dipilih untuk diteliti karena sesuai hasil analisis kurikulum biologi SMA, pembelajaran konsep ini berpotensi dilakukan melalui praktikum virtual. Konsep-konsep daur biogeokimia, meskipun dekat dan berada di lingkungan nyata siswa, namun bersifat abstrak dan sulit dijangkau atau ditelusuri secara langsung dalam waktu singkat. Sebagai contoh, pada proses daur air. Sesungguhnya proses daur air itu nyata dan dekat dengan siswa, namun untuk menelusuri proses perubahannya secara alami di alam sangat sulit dan perlu waktu relatif lama. Daur fosfor dan daur karbon juga terjadi di alam dan dekat dengan siswa, tetapi perubahan fosfor dan karbon itu sendiri sangat abstrak.

\section{METODE}

Penelitian ini dilakukan di SMA Negeri 1 Bandar Sribhawono Lampung Timur dengan seluruh siswa kelas $\mathrm{X}$ sebanyak 10 kelas sebagai populasi. Sampel penelitian dipilih secara cluster random sampling. Hasil acak kelas terpilih kelas X1 sebagai kelas eksperimen. Mengingat desain weak eksperiment dikatakan lemah, maka pada pelaksanaan penelitian ditambahkan kelas lain sebagai replikasi yang juga dipilih secara acak yaitu kelas X2 untuk meminimalkan kelemahan ini.

Penggunaan kelas replikasi bertujuan untuk memperkuat hasil penelitian. Artinya, apabila terdapat perbedaan antara pretest-posttest kelas eksperimen dan replikasi secara konsisten, dapat diyakinkan bahwa perbedaan memang dihasilkan dari perlakuan (Fraenkel dan Wallen, 2007). Agar validitas internal penelitian ini terjaga, peneliti berupaya semaksimal mungkin mengendalikan variabel-variabel ekstra pada kedua sampel penelitian. Adapun variabel yang dikendalikan yaitu pada kedua kelas sampel: (1) pembelajaran dilakukan oleh guru atau peneliti yang sama; (2) pembelajaran 
dilakukan pada konsep yang sama; (3) kemampuan awal siswa homogen; (4) mendapat perlakuan dengan metode yang sama; (5) kemampuan siswa diukur dengan instrumen yang sama; (6) evaluasi dan proses pembelajaran dilakukan pada waktu dan kondisi yang sama.

Desain penelitian yang digunakan adalah weak experiment design. Desain ini dipilih karena belum diketahui pembelajaran yang setara pengalaman belajarnya dengan praktikum virtual untuk digunakan sebagai kelas kontrol. Peningkatan hasil belajar siswa yang akan diukur adalah keterampilan berpikir kritis melalui pretest dan posttest, sehingga desain penelitian yang digunakan adalah the one-group pretest-posttest design.

\section{HASIL DAN PEMBAHASAN}

Berdasarkan penelitian dengan menerapkan praktikum virtual pada konsep daur biogeokimia, diperoleh data nilai keterampilan berpikir kritis siswa pada kedua kelas diuraikan sebagai berikut.

Perhitungan selisih nilai sikap awal dan sikap akhir digunakan untuk melihat peningkatan sikap ilmiah siswa siswa sebelum dan setelah pembelajaran. Hasil perhitungan selisih sikap ilmiah pada siswa kelas X1 dan kelas X2 ditampilakan pada Tabel 1.

Tabel 1 Rekapitulasi Sikap Ilmiah Siswa

\begin{tabular}{|c|c|c|c|c|}
\hline Kelas & $\begin{array}{l}\text { Rerata sikap } \\
\text { awal }\end{array}$ & $\begin{array}{l}\text { Rerata sikap } \\
\text { akhir }\end{array}$ & $\begin{array}{l}N- \\
\text { Gain }\end{array}$ & $\begin{array}{l}\text { Peningkata } \\
\mathrm{n}\end{array}$ \\
\hline X1 & 2,58 & 2,89 & 0,21 & Rendah \\
\hline $\mathrm{X} 2$ & 2,54 & 2,72 & 0,12 & Rendah \\
\hline
\end{tabular}

Berdasarkan Tabel 1, terjadi peningkatan keterampilan berpikir kritis siswa kelas X1 dan X2 setelah diterapkan praktikum virtual. Ditinjau dari N-Gain, menurut Meltzer 
(2002) sikap ilmiah siswa pada kelas X1 $(0,21)$ kategori rendah dan kelas X2 $(0,12)$ kategori rendah.

Data selanjutnya diuji hipotesis menggunakan paired sample t-test. Hasil uji hipotesis ditampilkan pada Tabel 2.

Tabel 2. Hasil Uji Hipotesis Sikap Ilmaih Siswa

\begin{tabular}{cccc}
\hline Kelas & $\mathbf{N}$ & $\mathbf{T}$ & Sig \\
X1 & 30 & -12.70 & 0,00 \\
X2 & 34 & -7.199 & 0,00 \\
\hline
\end{tabular}

Berdasarkan Tabel 2, diketahui nilai signifikansi sebesar $0,00<\alpha(0,05)$, sehingga Ho ditolak dan $\mathrm{H}_{1}$ diterima, artinya terdapat peningkatan secara signifikan sikap ilmiah siswa kelas $\mathrm{X} 1$ dan $\mathrm{X} 2$ setelah diterapkan praktikum virtual pada konsep daur biogeokimia. Agar dapat dilihat peningkatan sikap ilmiah siswa kelas X1 dan X2 pada tiap indikator, data ditabulasi dan ditampilkan pada Gambar 1.
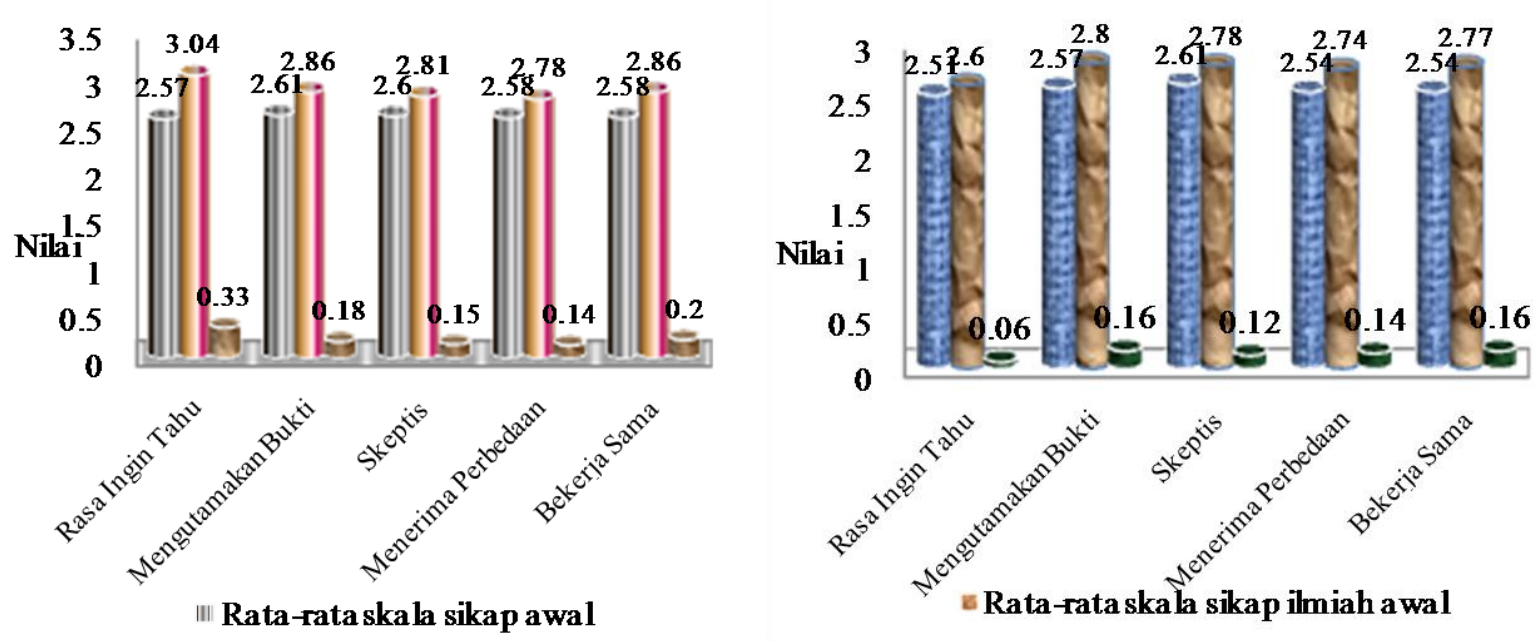

Gambar 1. Peningkatan Sikap Ilmiah Siswa Kelas X1 dan X2 
Berdasarkan Gambar 1, nilai rata-rata tiap aspek sikap ilmiah siswa seluruhnya mengalami peningkatan. Ditinjau dari nilai $N$-Gain pada masingmasing aspek sikap ilmiah siswa, aspek rasa ingin tahu yang meningkat dengan kategori sedang, sementara, aspek-aspek lain meningkat dengan kategori rendah. Aspek rasa ingin tahu dicapai siswa dengan perolehan $N$-Gain tertinggi $(0,33) . N$ Gain terendah dicapai pada aspek menerima perbedaan $(0,14)$.

Selanjutnya pada Gambar 2, Peningkatan sikap ilmiah siswa pada kelas X2 terjadi pada tiap aspek. Terdapat perbedaan dengan kelas X1 pada aspek rasa ingin tahu. Pada aspek ini kelas X1 meningkat dengan kategori sedang, sementara pada kelas X2 meningkat dengan kategori rendah. Sementara, pada kelas X2, peningkatan sikap ilmiah pada aspek lain yaitu mengutamakan bukti, skeptis, menerima perbedaan, dan kerjasama berada pada kategori rendah. Berbeda dengan kelas $\mathrm{X} 1$, pada kelas $\mathrm{X} 2 \mathrm{~N}$-Gain terendah justru dicapai siswa pada indikator rasa ingin tahu $(0,06)$. $N$-Gain tertinggi dicapai siswa pada indikator mengutamakan bukti $(0,16)$ dan bekerjasama $(0,16)$.

Pada penelitian ini, diketahui praktikum virtual secara signifikan $(\alpha>$ 0,05) meningkatkan sikap ilmiah siswa pada konsep daur biogeokimia (X1 kategori rendah $N$-Gain $=0,21 ;$ X2 kategori rendah $N$-Gain $=0,12$ ). Temuan ini berarti praktikum virtual pada konsep daur biogeokimia secara konsisten meningkatkan sikap ilmiah siswa kelas $\mathrm{X}$ pada rangkaian waktu yang berbeda. Peningkatan ini terjadi karena praktikum virtual dapat memfasilitasi siswa melatih sikap ilmiahnya dengan kegiatan penyelidikan konsep-konsep daur biogeokimia. Melalui praktikum virtual, siswa dapat secara aktif menemukan konsep-konsep daur biogeokimia yang disajikan secara virtual. 
Pada saat melakukan praktikum virtual, siswa dihadapkan pada tiga kegiatan praktikum yaitu jelajah alam, praktikum daur air, dan praktikum daur karbon-oksigen. Selanjutnya, siswa dibimbing melakukan praktikum sesuai prosedur yang disediakan dalam LKS. Setelah siswa memperoleh data-data praktikum, siswa dibimbing menginterpretasikan data, membuat kesimpulan, serta mengaitkan data-data tersebut dengan teori.

Peningkatan sikap ilmiah siswa pada konsep daur biogeokimia ini menunjukkan bahwa praktikum virtual dapat menyebabkan terjadinya perubahan pada sikap siswa. Perubahan sikap ilmiah ini menunjukkan bahwa sikap seseorang bersifat dinamis atau dapat mengalami perubahan karena adanya proses pembelajaran. Hal ini senada dengan pendapat Dayaksini dan Hudaniyah (2006) yang menyatakan bahwa sikap bukan suatu pembawaan, melainkan hasil interaksi antara individu dengan lingkungannya, sehingga sikap bersifat dinamis. Sikap dapat berubah karena kondisi dan pengaruh yang diberikan. Sikap dapat pula dinyatakan sebagai hasil belajar, sehingga sikap tidak dibentuk dengan sendirinya karena sikap senantiasa akan berlangsung dalam interaksi manusia berkenaan dengan objek tertentu. Jadi kegiatan praktikum virtual pada konsep daur biogeokimia ini dapat memberikan pengaruh positif terhadap perubahan sikap ilmiah siswa.

Berdasarkan analisis sikap ilmiah siswa pada tiap indikator, peningkatan sikap ilmiah siswa pada kedua kelas sampel umumnya termasuk kategori rendah, kecuali pada aspek rasa ingin tahu siswa pada kelas X1 meningkat dengan kategori sedang. Rendahnya peningkatan ini karena waktu yang dilakukan untuk mengembangkan sikap ilmiah dalam diri siswa belum memadai. Sebagaimana 
keterbatasan waktu dalam pengembangan keterampilan berpikir kritis siswa, waktu untuk mengembangkan sikap ilmiah siswa juga terbatas, sehingga peningkatannya belum optimal. Hal ini sesuai dengan pendapat Galaud dan Hukins (2002) yaitu "scientific attitudes are a composite of a number of mental habits, or tendencies to react consistently in certain ways to a novel or problematic situation", sehingga dibutuhkan waktu yang cukup lama dan konsisten untuk mengembangkan sikap ilmiah. Selain itu, belum optimalnya peningkatan sikap ilmiah siswa karena sebelumnya siswa kurang terampil dalam mengoperasikan fitur-fitur praktikum virtual. Hal ini, terlihat dari berbagai kebingungan siswa mengenali alat-alat praktikum, pengoperasian fitur-fitur praktikum, dan melaksanakan tahapan-tahapan praktikum.

Pada penelitian ini, lima aspek sikap ilmiah yang menjadi fokus yang dikembangkan atau dilatihkan kepada siswa. Peningkatan sikap ilmiah pada setiap aspek dianalisis pada masing-masing kelas sampel. Berdasarkan analisis sikap ilmiah siswa pada tiap aspek di kelas (Gambar 4.5) diketahui bahwa terjadi peningkatan sedang pada aspek "rasa ingin tahu" $(N$-Gain $=0,33)$. Peningkatan ini disebabkan sejak awal siswa dilatih untuk membuat rumusan masalah sebelum melaksanakan kegiatan praktikum virtual. Program praktikum virtual yang masing tergolong baru bagi siswa, secara tidak langsung turut menumbuhkan rasa penasaran atau rasa ingin tahu siswa. Selain itu, pada praktikum virtual konsep daur biogeokimia ini siswa dihadapkan pada topik yang menarik dan dekat dengan siswa, sehingga dapat menumbuhkan keinginan siswa untuk berpraktikum dan menggali informasi lebih banyak. Hal ini sesuai pernyataan Krech et al. (1962) bahwa salah satu faktor yang mempengaruhi sikap seseorang adalah 
keinginan (want). Adapun peningkatan aspek rasa ingin tahu yang belum optimal sebagaimana didukung hasil analisis pada kelas X2 $(N$-Gain $=0,06)$ diduga karena beberapa siswa belum mampu menterjemahakan atau mengkonstruksi makna kegiatan merumuskan masalah sebagai bagian dari pembentukan sikap rasa ingin tahu.

Pada aspek lain seperti "mengutamakan bukti" dicapai siswa dengan peningkatan rendah $(N$-Gain siswa kelas $\mathrm{X} 1=0,18 ; \mathrm{X} 2=0,18)$. Meningkatnya keterampilan siswa pada aspek mengutamakan bukti ini karena dalam kegiatan praktikum virtual, siswa dibimbing melakukan penyelidikan dan membuktikan konsep-konsep daur biogeokimia. Hal ini yang dapat melatih siswa membangun sikap mengutamakan bukti pada dirinya. Praktikum virtual juga dapat meningkatkan jiwa "skeptis" siswa dengan kategori peningkatan rendah ( $N$-Gain siswa kelas $\mathrm{X} 1=0,15 ; \mathrm{X} 2=0,12$ ). Praktikum virtual konsep daur biogeokimia ini didesain agar dapat diulang. Dengan demikian, siswa dapat benar-benar paham dan yakin dengan hasil praktikumnya. Pada teknis pelaksanaan sengaja memberikan praktikum virtual yang hasilnya berbeda, sehingga menggugah dan menantang siswa untuk berpikir dan mengkaji kembali hasil praktikum. Melalui kegiatan tersebut siswa dilatih untuk menumbuhkan jiwa skeptis. Hal ini sesuai pendapat Domingues et al. (2010) bahwa laboratorium virtual dapat secara otomatis diulang, sehingga dapat meningkatkan kualitas eksperimen, karena memungkinkan untuk diulang untuk memperjelas keraguan dalam pengukuran di laboratorium. Siswa atau mahasiswa dapat semakin lama menghabiskan waktunya dalam laboratorium virtual tersebut berulang-ulang, 
Pada aspek "menerima perbedaan" dicapai siswa dengan peningkatan rendah $(N$-Gain siswa kelas $\mathrm{X} 1=0,14 ; \mathrm{X} 2=0,14)$. Pada kegiatan praktikum virtual ini, siswa dibimbing untuk aktif bekerjasama, berdiskusi atau berinteraksi dengan siswa lain guna memecahkan masalah-masalah dalam LKS. Melalui kegiatan ini, muncul berbagai perbedaan pendapat, pemahaman, dan kecepatan dalam menjalankan program praktikum virtual. Mengantisipasi bebagai pertentangan ini, siswa dibimbing saling beradaptasi dengan berbagai situasi, sehingga menumbuhkan sikap "menerima perbedaan" dalam diri siswa. Kondisi tersebut sejalan dengan pendapat Krech et al. (1962) bahwa salah satu faktor yang dapat mempengaruhi sikap seseorang adalah afiliasi kelompok (the group affiliations). Melalui praktikum virtual ini, siswa dilatih untuk saling beradaptasi dan menerima berbagai perbedaan pandangan dengan siswa lain untuk mencapai kesimpulan pemecahan masalah yang tepat. Hal ini sejalan dengan pendapat Azwar (2009) bahwa beberapa faktor yang sangat berpengaruh dalam pembentukan sikap ilmiah siswa antara lain pengalaman pribadi, orang lain yang dianggap penting, faktor emosi dalam diri, dan kebudayaan di lingkungan sekitarnya. Adapun belum optimalnya peningkatan sikap menerima perbedaan siswa disebabkan karena kurangnya waktu untuk melatih siswa saling beradaptasi. Beberapa siswa juga memiliki kecenderungan unik bahwa dalam satu kelas, jika ada temuan yang berbeda atau pendapat siswa lain yang terlau berbeda dengan siswa atau kelompok lain justru dianggap aneh.

Sikap mau bekerja sama juga sangat penting dikembangkan dalam diri siswa, mengingat bahwasanya manusia adalah makhluk sosial yang perlu bekerja sama. Melalui pemeblajaran berbasis praktikum virtual ini, siswa dilatih untuk 
menumbuhkan sikap tersebut melalui diskusi. Hasilnya terjadi peningkatan signifikan baik pada kelas X1 $(N$-Gain $=0,2)$ dan kelas X2 $(N$-Gain $=0,16)$ dengan kategori rendah. Program praktikum virtual didesain dengan permasalahan-permasalahan rumit dan kontekstual, sehingga yang tidak semua siswa mampu menyelesaikannya dengan kemampuan yang sama. Hal ini menandakan bahwa siswa memiliki ZPD berbeda-beda terhadap suatu konsep tertentu, sehingga diperlukan orang lain untuk membantu menyelesaikan masalah tersebut (scaffolds).

Berkaitan dengan scaffolds, Vygotsky (1978) menyatakan bahwa interaksi sosial memainkan peran yang mendasar dalam perkembangan kognisi. Belajar terjadi melalui partisipasi siswa dalam pengalaman-pengalaman sosial dan kultural yang sengaja ditanamkan.

Siswa berkembang fungsi budaya dan psikologisnya melalui keterlibatan dalam praktik budaya masyarakat dan berinteraksi dengan warga masyarakat yang lebih tahu. Dalam kerjanya, Vygotsky memiliki dua prinsip utama yaitu the more knowledgeable other (MKO) dan the zone of proximal development (ZPD). MKO merupakan seseorang yang memiliki pemahaman yang lebih baik atau tingkat kemampuan yang lebih tinggi daripada siswa, contohnya guru, orang dewasa, teman sebaya anak atau orangtua anak (Galloway, 2006).

Pada kegiatan praktikum virtual ini, siswa diarahkan untuk melakukan penyelidikan secara berkelompok. Setiap kelompok terdiri atas anggota-anggota heterogen, sehingga dalam kelompok tersebut dimungkinkan ada MKO yang dapat membantu siswa lain. Selain itu, dalam setiap proses pembelajaran, siswa juga dibimbing oleh guru yang berperan sebagai MKO. Hal inilah yang dapat 
meningkatkan sikap mau "bekerja sama" siswa. Adapun belum optimalnya peningkatan sikap pada aspek ini, diduga karena praktikum virtual sebagian besar dikerjakan pada laptop masing-masing siswa, sehingga beberapa siswa cenderung lebih nyaman ketika bekerja sendiri.

Pada intinya, kekurangan waktu pada kegiatan pembelajaran menjadi faktor utama yang menjadi kendala mengembangkan sikap ilmiah siswa. Setelah dikaji lebih lanjut, ada beberapa hal lain yang menjadi catatan penting penyebab rendahnya peningkatan sikap ilmiah siswa pada konsep daur biogeokimia melalui praktikum virtual antara lain: (1) pada saat pembelajaran, beberapa kali terjadi kesalahan teknis yaitu program menjadi lambat, sehingga siswa kecewa atas kejadian tersebut; (2) skala sikap diberikan pada urutan paling belakang, sehingga waktu pengerjaan soal cenderung terbatas. Hal ini memungkinkan siswa tidak fokus lagi memahami pernyataan-pernyataan pada soal sikap ilmiah; (3) siswa cenderung memilih jawaban aman, opsi yang banyak dipilih adalah S (setuju) dan TS (tidak setuju), opsi SS (sangat setuju) dan STS (sangat tidak setuju) tidak banyak dipilih. Dengan memilih opsi SS dan TS mengakibatkan perubahan skor hanya sedikit (4) beberapa siswa masih berharap bahwa praktikum konsep daur biogeokimia dilakukan secara ril di lapangan.

Berdasarkan pengalaman menerapkan praktikum virtual pada konsep daur biogeokimia ini, peneliti menemukan keunggulan-keunggulan praktikum virtual diantaranya proses pembelajaran lebih menarik, lebih interaktif, hemat waktu, kualitas belajar meningkat, proses belajar mengajar dapat dilakukan di mana saja dan kapan saja, memudahkan siswa mempraktikumkan konsep-konsep abstrak, seperti daur air dan daur karbon, dapat digunakan berulang-ulang bahkan sampai 
pada pembelajaran di semester berikutnya tanpa harus menyiapkan alat dan bahan kembali. Temuan ini sejalan dengan pendapat Domingues et al. (2010), beberapa manfaat yang dapat diperoleh dengan menggunakan laboratorium virtual adalah hemat waktu, ekonomis, meningkatkan kualitas eksperimen, meningkatkan efektivitas pembelajaran, meningkatkan keamanan dan keselamatan.

Adapun kelemahan-kelemahan praktikum virtual yang ditemui antara lain Tampilan-tampilan fitur pratikum virtual yang dibuat peneliti seperti pada praktikum jelajah alam belum mampu menggambarkan dinamika ekosistem yang benar-benar mirip dengan ekosistem sesungguhnya. Fitur-fitur praktikum virtual masih terkesan kaku dan belum lengkap karena hanya mempraktikumkan daur karbon dan daur air.

\section{SIMPULAN DAN SARAN}

Berdasarkan hasil analisis data, pengujian hipotesis, dan pembahasan dalam penelitian ini, dapat disimpulkan bahwa praktikum virtual pada konsep daur biogeokimia secara signifikan dapat meningkatkan keterampilan berpikir kritis siswa kelas X. Peningkatan ini karena praktikum virtual dapat memberikan pengalaman pada siswa untuk merumuskan masalah, melakukan penyelidikan, menginterpretasi data, dan membuat kesimpulan, sehingga meningkatkan sikap ilmiahnya.

Sesuai pengalaman menerapkan praktikum virtual pada konsep daur biogeokimia ini, peneliti menyarankan beberapa hal diantaranya pada pelaksanaan praktikum sebaiknya disediakan sarana dan prasarana seperti laptop atau komputer yang memadai baik dari segi jumlah dan kualitasnya; Siswa harus 
benar-benar dipastikan memahami cara-cara mengoperasikan komputer dan mengoperasikan fitur-fitur yang ada pada program virtual, artinya waktu untuk adaptasi perlu ditambah agar siswa lebih familiar dengan program virtual; Perlu dilakukan penelitian lanjutan dengan durasi yang lebih lama dengan konsep berbeda untuk memenuhi kriteria bahwa pengembangan ketreampilan berpikir kritis siswa perlu dilatihkan dalam proses secara terus menerus dan konsisten.

\section{DAFTAR PUSTAKA}

Azwar, S. (2009). Sikap Manusia Teori dan Pengukurannya. Yogyakarta: Pustaka Pelajar.

Carin, A.A. (1997). Teaching Modern Science. New Jersey. Prentice Hall.

Carin, A. A. and Sund, R. B. (1989). Teaching Science through Discovery. Ohio: Charles E. Merril Publishing.

Carnevale, D. (2003). The Virtual Lab Experiment. [Online]. Tersedia: http: //chronicle.com/:weekly/v49/i21/21a03001.html(25 September 2012)

Departemen Pendidikan Nasional. (2006). Permendiknas Nomor 22 Tahun tentang Standar Kompetensi dan Kompetensi Dasar Kurikulum Tingkat Satuan Pendidikan. Jakarta: Depdiknas.

Departemen Pendidikan Nasional. (2010). Bahan Pelatihan Penguatan Metodologi Pembelajaran berdasarkan Nilai-nilai untuk Membentuk Daya Saing dan Karakter Bangsa Pengembangan "Penguatan Budaya dan Karakter Bangsa”. Jakarta: Depdiknas.

Duran, M and Ozdemir. (2010). The Effect of Scientific Process Skill-Based Science Teaching on Student's Attitudes towards Science. Dalam USChina Education Review [Online], Vol 7(12). Tersedia: http://www.teacher .org.cn/doc/uced201003/ucedu20100302.pdf. [1 Juli 2013]

Fraenkel, J. and Wallen, N. (2007) How to Design and Evaluate Research in Education "Sixth Edition" Published by McGraw-Hill Companies, lnc; 1221 Avenue of the Americas, New York, NY, 10020. Copyright@2006.

Galaud, C.F. and Hukins, A.A. (2002). What is Scientific Attitudes. [Online]. Tersedia: http://en.Wkipedia.Org/wiki/Scienceeducation. [21 Juni 2103] 
Maldarelli, G., Hartmann, E., Cummings, P., Horner, R. Obom, K., Shingles, R., and Pearlman, R. (2009). "Virtual Lab Demonstrations Improve Students' Mastery of Basic Biology Laboratory Techniques". Journal of Microbiology \& Biology Education, 10, 51-57.

Rustaman, N.Y., Dirdjosoemarto, S., Yudianto, S.A., Achmad, Y. Subekti, R., Rochintaniawati, D., Nurjani, M.(2003). Strategi Belajar Mengajar Biologi Common Text Book. Jurusan Pendidikan Biologi FPMIPA UPI.

Rustaman, N.Y. (2010). Pengembangan Pembelajaran Sains Berbasis Kemampuan Dasar Bekerja Ilmiah. Dalam Topik Hidayat et al., (Eds.). Teori, Paradigma, Prinsip, dan Pendekatan Pembelajaran MIPA dalam Konteks Indonesia. Bandung: FPMIP ,211-247. 